\title{
Application Of School And Community Cooperation Models In Improving Student Learning Achievement Based On Local Knowledge
}

\author{
$1^{\text {st }}$ Helmuth Y. Bunu ${ }^{1}, 2^{\text {nd }}$ Yunike Wati ${ }^{2}, 3^{\text {rd }}$ Endang Purwaningsih ${ }^{3}$ \\ $\left\{\right.$ hyb047@yahoo.co.id ${ }^{1}$,yunike.wati@yahoo.com ${ }^{2}$, enda_purwa@yahoo.com ${ }^{3}$ \}
}

Lecturer of Teacher Training and Education Faculty of Palangka Raya University. Jl. Yos Sudarso

City Palangkara Central Kalimantan Inonesia $73112^{1}$, Lecturer of Economics Faculty of Palangka Raya University. Jl. Yos Sudarso City Palangkara Central Kalimantan Inonesia $73112^{2}$, Lecturer of Law

Faculty of Yarsi University, Jl Letjen Suprapto Cempaka Putih Central Jakarta. Indonesia. $10510^{3}$

\begin{abstract}
The purpose of this study was to determine the effectiveness of the implementation of school and community collaboration models in improving student learning achievement based on local knowledge. The method used in this study is action research with a participatory qualitative approach. Based on the results of the second year study, it can be concluded that: 1) the application of the model is carried out with active participation of the community and schools and the alignment of related institutions such as the neighborhood association (RT), the neighborhood association (RW), the village head (Lurah), the head of the sub-district (Camat), and local government, as well as parties from the campus is very important for increasing parents' awareness of education children according to the model produced in the first year. 2) in the implementation of the model (second year) there are still obstacles, including lack of assistance from the sub-district and city districts. Regarding the motivation (and mindset) of the community to send their children to school is higher than when they do not have an understanding of the meaning of education for children.
\end{abstract}

Keywords: School, Community, Models, Improving Student Learning Achievement, Local Knowledge.

\section{Introduction}

Based on the results of the research in the first stage, the following problems can be identified: 1) the people who live in very slum and densely populated villages in Pahandut Village, Pahandut Sub-District, Palangkaraya City, Central Kalimantan are in very poor condition; 2) the motivation of children to study both in the evening and at night is very low, as evidenced by the large number of children playing outside the home; 3 ) the rate of transition to junior high school is very low at only $35 \%$ so that the remaining $65 \%$ do not continue to junior high school, the transitional number going to high school is only $20 \%$ so the remaining $80 \%$ do not continue to high school level, and the transition to college is only $2 \%$ and the remaining $98 \%$ are not in college.

In the afternoons and evenings, children always chase, dress naked, swim in the slum swamps under their houses, children ride motorcycles in narrow alleys, play rummy, play 
ding-dong coins, playing games on-line with hand phone, and "carambol games" betting Rp $2,000.00 /$ game.

It is not uncommon for children to play from day to night interspersed with the habit of sucking glue (gluing), smoking, playing guitar, drinking hard, staying up late, "sing a song Dangdut", and other non-beneficial activities until late at night even into the morning.

There is absolutely no parent and community who care about children's education at home and in the social environment. All parents are busy with their respective livelihoods without regard to children's education. The majority of them make a living looking for fish in rivers and lakes, raising fish in "karamba", trading small-scale, selling fish in the market, becoming parking attendants, drivers, opening small grocery stalls on the porch of the house, opening snacks, drinks and snacks, and work in other informal sectors.

The entire community of Pahandut Village, Pahandut Subdistrict, Palangkaraya City, which numbered more than 2000 families and the majority lived on the banks of the Kahayan River with very poor economic conditions, the condition of the majority of the houses was very poor, the distance between one house and the other was very tight, no social space that can be used by children and the community to play freely, slums physical environment, under the house is always flooded with swamp water does not flow with a water depth of 1 to 3 meters, with very dirty and brownish water conditions even many which is black.

Their settlements are really in a dense condition with very narrow alley conditions, under their houses full of garbage, hot, barren atmosphere, no plants at all except swamp plants, or just one two potted plants planted in front of community houses in untreated conditions and trails are full of junk and garbage.

All of the above problems indicate that: 1) the learning interest of children in Pahandut Sub-district, Palangkaraya City is very low, 2) parental participation in children's learning is very low, 3) participation of community leaders, religious leaders, youth leaders, traditional leaders, and figures others also paid little attention to the level of education of children, and 4) Kelurahan Social Institutions (LKK), supra village institutions, NGOs, PKK, youth groups, and other institutions also paid little attention to the level of education of children.

\section{Theoretical basis}

Local wisdom comes from two words, wisdom, and local. In general, local wisdom can be understood as local (local) ideas that are wise, full of wisdom, good value, embedded and followed by members of the community. As Sartini (2006; Qodariayah and Armiyati, 2013, 2013) wrote, that the function of local wisdom is (1) conservation and preservation of natural resources; (2) human resource development; (3) the development of culture and science; (4) advice, trust, literature and abstinence; (5) social meaning such as communal / kinship integration ceremonies; (6) means ethics and morals; (7) meaning politically, for example the bowl bowing ceremony and Atmodjo's patron client power (1986: 37), local wisdom is the ability to absorb foreign culture that comes selectively, meaning that it is adapted to local circumstances and conditions. (Qodariayah and Armiyati, 2013).

The results of research conducted by Zaremba et al (2014) show that 1) the values of Sasak local wisdom as a living guide for the people in Lingsar Village are categorized in the political, social, economic, trade, agricultural and cultural preservation fields; 2) the values of multicultural-minded "Sasak" local wisdom focus on the social field. 
Every society has traditional knowledge and technology called "knowledge of rural people". Traditional knowledge and technology, if handed down from generation to generation into tradition. A tradition is very broad in scope, one of which is traditional wisdom. Keraf (2006: 4) suggests that traditional wisdom is not only related to knowledge, understanding and customs about humans, nature and how good relations between people, but also concerning knowledge, understanding, and customs about humans, nature, and how relations among all residents of the ecological community.

The end of this sedimentation of local wisdom will become a tradition or religion. In our society, local wisdom can be found in songs, proverbs, advice, slogans, and ancient books that are inherent in everyday behavior. Local wisdom is usually reflected in people's longstanding life habits.

The collective picture is part of the content of the collective consciousness, an entity that exists between the metaphysical group mind and the more prosaic reality of public opinion. Collective awareness contains all the ideas shared by individual members of society and which are collective goals and intentions (Campbell, 1994: 179-180).

Mechanical solidarity is based on a "collective consciousness (conscience), which refers to" the totality of shared beliefs and sentiments which on average exist in the same community. It is a solidarity that depends on individuals which has the same characteristics and adheres to the same beliefs and normative patterns. Therefore, individuality does not develop, individuality is constantly paralyzed by immense pressure for confirmation (Soerjono Soekanto, 1985: 4-9).

According to the theory of rationality, humans are assumed to be rational beings. That is, humans always adhere to the principle of efficiency and effectiveness in carrying out each action (Basrowi and Sukidin, 2003; Mustain, 2007). In connection with that, every human individual in the life of society has an awareness of the benefits that can be gained through his actions (Yunita, 1986: 68-69). Likewise, selective incentive theory assumes that a person's rational participation in an activity is influenced by the type, form, and content of expectations that will be beneficial.

Local wisdom has six dimensions, namely:

1. Dimensions of local knowledge. Every community where they are located always has local knowledge related to their environment.

2. Dimensions of local values. To regulate the life between citizens, every community has rules or values that are adhered to and kicked by the same members by all members.

3. Dimensions of local skills. Local skills for each community are used as an ability to survive. Local skills are usually only sufficient and able to meet the needs of their respective families or referred to as a subsistence economy.

4. Dimensions of local resources. Local resources in general are natural resources. The community will use local resources according to their needs and will not exploit on a large scale or be commercialized. This local resource has been divided into uses such as forests, gardens, water sources, agricultural land and settlements. This ownership of local power is usually collective.

5. Dimensions of local decision-making mechanisms. Every society basically has its own local government or is called a tribal government. Tribe is a legal entity that governs its citizens to act as citizens. Each community has a different decision-making mechanism.

6. Dimension of local group solidarity. People have media to bind their citizens that can be done through religious rituals or other traditional ceremonies and ceremonies. Each member gives and receives each other in accordance with their respective fields of 
function such as in solidarity processing morning plants, community service and mutual cooperation.

The forms of local wisdom in society according to Aulia and Dharmawan (2010) can be in the form of values, norms, beliefs, and special rules. These various forms result in various functions of local wisdom. The functions of local wisdom include: (1) conservation and preservation of natural resources; (2) developing human resources; (3) the development of culture and science; and (4) instructions on advice, trust, literature, and abstinence. In addition, added by Sartini (2004) who expressed the functions and meanings of local wisdom including: (1) functioning for the conservation and preservation of natural resources; (2) function for the development of human resources for example relating to life cycle ceremonies, the concept of a rate pat; (3) function for the development of culture and science, for example in the "Saraswati" ceremony, belief and worship at the Panji temple; (4) function as advice, trust, literature, and abstinence; (5) social meaning, such as communal / kinship integration ceremonies; (6) meaning ethics and morals, which are manifested in the "Ngaben" ceremony and purification of ancestral spirits; and (7) meaning politically, for example the bowl bowing ceremony and patron client power. (Maridi, 2015).

\section{Research Methods}

This research is the second study (continued). This research is an action implementation model, with a research approach that is qualitative descriptive analysis to describe and analyze participatory approaches (PRA), and sociological-educative approaches in order to achieve the research objectives. In phase 1, Need assessment was carried out on profiles and aspirations, making a model for increasing public awareness of children's education.

In the second year, there were: 1) applying the model, 3) monitoring and accompanying the process of increasing public awareness of children's education, 4) increasing education participation rates, 5) discussing with the community, 6) drafting books, 7) networking expected to have occurred and expanded with entrepreneurs, 8) Focus Group Discussions, and 9) international seminars.

\section{Results and Discussion}

Nowadays human civilization is so advanced, as evidenced by the emerging modern cultures that have filled the dimensions of human life ranging from domestic life to the advancement of industrial technology and information. Likewise, the world of education today is far different from the educational models of ancient times. This indicates that the community has enjoyed the results of creativity, taste, and initiative in the form of modern cultural results. Various changes that occur in Indonesia are not only related to the socioeconomic life system, also politics, language and culture. Language contact results in cultural contact or otherwise cultural contact results in language contact (Suryani, 2014).

This happened because of the effects of the global world in the era of globalization. All distance and space feels close because of technological advances. In the midst of such advances, of course we cannot forget the existing cultural roots because those cultures contain very noble values that need to be preserved. That is the local wisdom that needs to be explored 
in addition to still enjoying modern culture. Escape from the existing local wisdom means denying the existence of high-value ancestors' cultural heritage (Suryani, 2014)

The model that has been produced in the first year research, and will be applied in the second year is as follows.

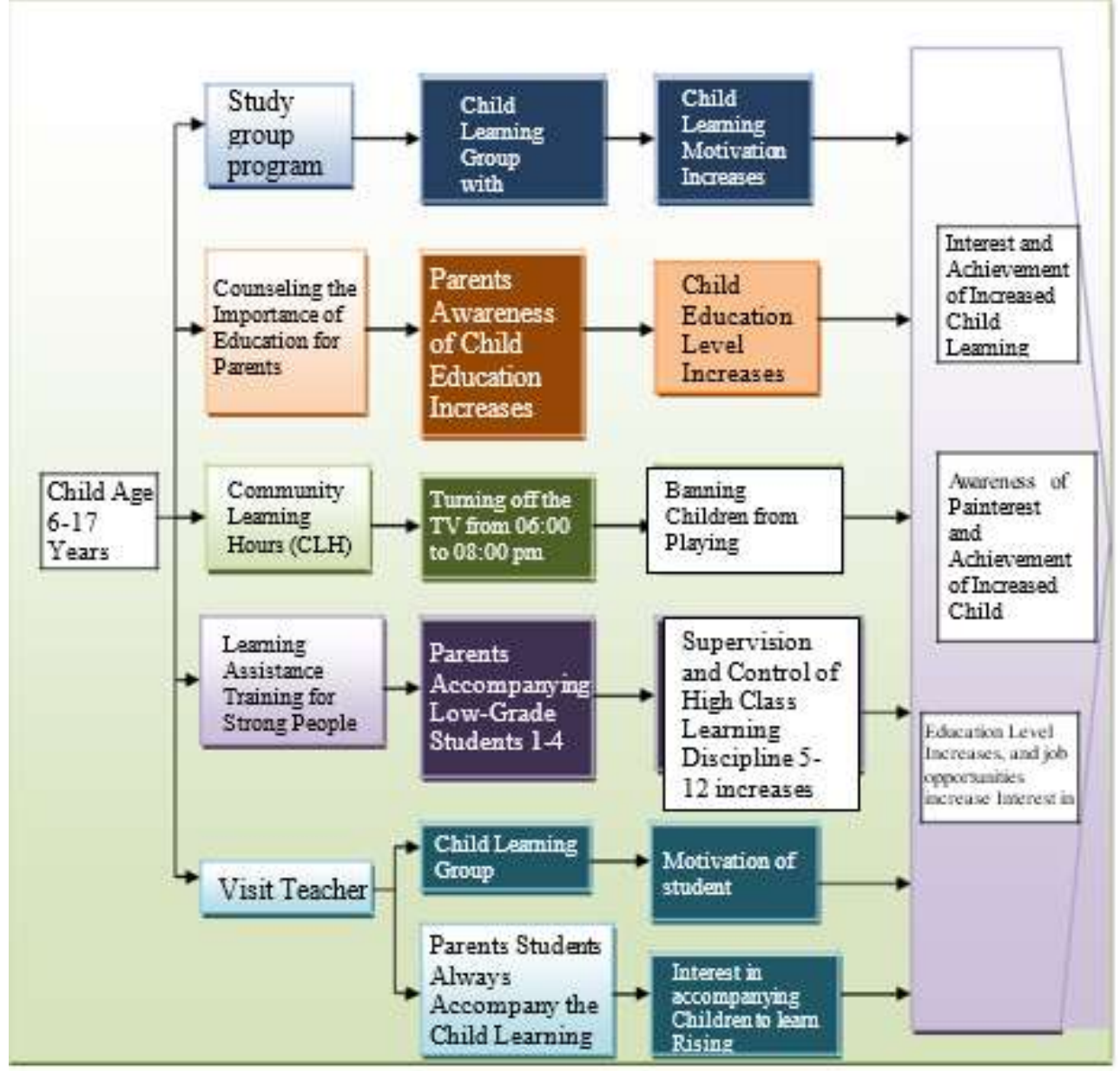

Figure 1. Model of Increasing Public Awareness of Children's Education

\section{Results of Providing Facilitation to the Community (year II)}

The purpose of facilitation to the community is that the community is willing to pay attention to children's education at home, whether doing homework, getting up in the morning, taking a shower, preparing breakfast, and textbooks, monitoring children's learning hours, the effectiveness of community learning hours (JBM), and various things relating to education enrollment rates, the transition rate of children's education to junior high school / MTs or to high school / vocational school / MA, or even the transition rate of education to tertiary education. The criteria for this research model are successful, if:

1. The level of awareness of parents about the meaning of children's education increases;

2. Dropout rate decreases; 
3. The level of awareness of parents to accompany children learning increases;

4. Number of children playing during community learning hours decreases;

5. The presence of group learning children increases;

6. The average value of children's report cards increases;

7. Ranking of student grade report cards increased;

8. The transition rate of children to SMP / MTs increases;

9. The transition rate of children to SMA / SMK / MA increases;

10. The transition rate of children to universities is increasing;

11. The level of awareness of parents in continuing children's education increases;

12. Attention of all education stakeholders from the principal, teacher, to the education office.

Based on the results of the study, all aspects mentioned above have increased significantly, so that the application of the model proposed in the research can be said to be successful, and can be applied to the wider community who have similar characteristics. Even though at first there were some components that had not yet improved, various components that had not yet improved were improved, and had been re-treated so that all the components that had been determined could increase significantly. When viewed differences before the research and after the research can be described as follows.

Table 1.The difference between before being treated and after counseling / awareness

\begin{tabular}{|c|c|c|}
\hline No & Before there is awareness & After awareness \\
\hline 1 & $\begin{array}{l}\text { There were no visible or audible } \\
\text { children studying at home both in the } \\
\text { afternoon and in the afternoon, there were } \\
\text { only many children watching TV, snacks } \\
\text { outside the house, and hanging around } \\
\text { playing outside the house, there were also } \\
\text { children playing cards, playing karambol } \\
\text { with money, chases, motorbikes, swimming } \\
\text { in swamps and rivers, cycling, smoking, } \\
\text { and other games that spend time studying. }\end{array}$ & $\begin{array}{l}\text { During study hours, the majority of children } \\
\text { are already seen and heard learning at home. } \\
\text { During study hours, there are no children } \\
\text { and parents watching TV, hanging around } \\
\text { and playing outdoors. During the study } \\
\text { hours, there were no children playing cards, } \\
\text { playing carol, running chasing, racing and } \\
\text { riding bicycles and motorbikes, smoking, } \\
\text { and other games. During school hours all } \\
\text { children study at home }\end{array}$ \\
\hline 2 & $\begin{array}{l}\text { There do not appear to be parents who care } \\
\text { about children's education. There were no } \\
\text { parents accompanying children to study, no } \\
\text { parents told their children to learn, no } \\
\text { parents looking for their children to study, } \\
\text { no community to turn off TV during } \\
\text { children's learning hours, and no concern } \\
\text { from the community for children's learning } \\
\text { motivation. }\end{array}$ & $\begin{array}{l}\text { All parents care about children's } \\
\text { education. The majority of parents } \\
\text { accompany children learning, telling their } \\
\text { children to learn. If the child is not at home, } \\
\text { parents look for their children to go home } \\
\text { and study, the community turns off the TV } \\
\text { during children's learning hours, and the } \\
\text { majority of people already care about } \\
\text { children's learning motivation }\end{array}$ \\
\hline 3 & $\begin{array}{l}\text { The majority of parents are reluctant to send } \\
\text { their children to junior high, high school, } \\
\text { especially to universities. They are psychic, } \\
\text { afraid of shadows, and afraid to stop in the } \\
\text { middle of the road. }\end{array}$ & $\begin{array}{l}\text { The majority of people have unanimous } \\
\text { determination and deep conviction that they } \\
\text { can afford to pay for their children's } \\
\text { education if they only enter junior high or } \\
\text { high school, although they still have to } \\
\text { lose their psychology, they must continue } \\
\text { to college (lecture). }\end{array}$ \\
\hline 4 & $\begin{array}{l}\text { With the economic condition of the } \\
\text { community which is very concerning, there } \\
\text { is no time and energy to pay attention to }\end{array}$ & $\begin{array}{l}\text { with any conditions, parents still take the } \\
\text { time to pay attention to children's } \\
\text { education and learning.. }\end{array}$ \\
\hline
\end{tabular}




\begin{tabular}{|c|c|c|}
\hline No & Before there is awareness & After awareness \\
\hline & children's education & \\
\hline 5 & $\begin{array}{l}\text { In the afternoon to night, children are always } \\
\text { seen playing interspersed with the habit of } \\
\text { smoking, playing guitar, staying up late, } \\
\text { and other non-benefit activities until late at } \\
\text { night, even if at night there are also staying } \\
\text { up until morning }\end{array}$ & $\begin{array}{l}\text { There are no more elementary and middle } \\
\text { school-aged children who smoke in the } \\
\text { home environment. There are also no } \\
\text { elementary and junior high school age } \\
\text { children who play gambling using game } \\
\text { tools. It's no longer a guitar that sounds } \\
\text { when learning hours and sounds above } \\
21: 00 \text {. }\end{array}$ \\
\hline 6 & $\begin{array}{l}\text { The community considers that education does } \\
\text { not have any meaning, is unable to provide } \\
\text { certainty for the future of children, and is } \\
\text { unable to improve children's welfare in the } \\
\text { future. They will only send their } \\
\text { children to elementary or junior high school. }\end{array}$ & $\begin{array}{l}\text { they assume that education is valuable } \\
\text { useful, and able to improve the dignity of } \\
\text { children and parents in the future }\end{array}$ \\
\hline
\end{tabular}

Source: results of 2017 data analysis

All reality after the implementation of the model as described above, indicates that:

1) the learning interest of children in the Pahandut District of Palangkaraya City has increased,

2) parental participation in children's learning has increased,

3) the participation of community leaders, religious leaders, youth leaders, traditional leaders, and other figures on the level of children's education has increased,

4) Parental awareness of children's education has increased,

5) awareness of parents to continue their education to high school / vocational high school / MA has increased, and

6) PKK Community Institutions, youth organizations, "dasa wisma", "Posyandu" groups, "pengajian" groups, "arisan" groups, and other institutions in paying attention to the level of education of children have also increased.

\section{Implementation or Implementation of the Model}

1. Formation of study groups at home by teachers in schools based on the closeness of the place of residence. The goal is that, children can learn groups with their classmates while at home. Thus, children's play time is not reduced, because their group learning activities are carried out together with playing to be reduced. Benefits gained: (1) children's ability to socialize with their peers increases, (2) Child Learning motivation increases; (3) Child Learning Achievement Increases

2. Counseling the Importance of Education for Children to Parents. This activity was first carried out on May 28, 2018 followed by 40 parents of student guardians, located in the class V study room of SDN 1 Pahandut. The second period, held on June 7, 2018 was attended by 42 parents of student guardians (with participants who were different from the first period participants), taking place in the V Classroom of Pahandut 1 Elementary School. This activity aims to increase parental awareness of children's education. Expected impact Child Education Levels Increas

3. Establishment of Community Learning Hours (JBM). This activity was formed at the RW level which was followed up at the RT level. The activity continued with making a $60 \times 40 \mathrm{~cm}$ banner containing JBM. This mini banner is installed in public places that are easy to read such as in the mouth of the alley, in RT houses, in the alleys, and in the gathering place of children. This activity aims to get children to concentrate on learning 
at 6:00 p.m. 8:00 p.m. at that time all children in the Pahandut village were in the house, and all parents turned off the TV, did not play cellphones, and other activities that could interfere with their learning children. When there is a house with an open door, turning on the TV aloud, the RT head comes to the house to close his house, turn off the TV, and accompany his child to study. When during study hours, there are school-age children, parents, caring communities, the RT head will send their children home and study.

4. Learning Assistance Training for Parents. The objectives to be achieved are Supervision and Control of Learning Discipline of Children in Class 1 s.d 4 Elementary School can be increased and Supervision and Control of Class 5 Children's Learning Discipline until 6 elementary school and 7th grader 9 junior high school increases. This activity was held in the neighborhood association (RW) 26 on May 21, 2018 at 6:00 p.m. 20. In this activity, parents are trained in how to accompany their children who are still in grade 1-4 elementary school. Parents are briefed on how to assist children in learning and how to motivate children to learn more diligently

5. Teacher Visit. The steps taken are the teacher spontaneously, periodically and not scheduled to visit the Child Study Group. This activity has been scheduled by the principal of the state basic school (SD Negeri) 1 to visit their students who are studying groups both evening and night. The schedule is confidential, so no one student knows that the study group will get a visit from the teacher. Every teacher starts class 1 teacher. Class VI including teachers of Christian and Islamic education visited 3-4 groups in 1 week. When the teacher visits the children's study group, the children can directly ask about various difficulties that the child experiences while learning, or ask for other knowledge that is still related to the subject. This aims, so that children feel they get supervision from the teacher even though they are studying at home. Thus, children's enthusiasm for group learning at home is increasing, and children's learning achievement is also increasing.

\section{Evaluation of Model Implementation}

After all stages in the model are implemented, the next step is evaluating the implementation of the model. In this evaluation phase, there are various weaknesses of the model that must be addressed immediately, so that the model that has been built can be implemented as well as possible. There are several advantages and disadvantages of implementing the model as follows.

Table 2. Strengths and Weaknesses of Model Implementation

\begin{tabular}{|c|c|c|c|}
\hline No & Aspect & $\begin{array}{c}\text { Excess } \\
\end{array}$ & Weaknesses \\
\hline \multirow[t]{3}{*}{1} & \multirow[t]{3}{*}{$\begin{array}{l}\text { during the socialization } \\
\text { of the importance of } \\
\text { education for children }\end{array}$} & $\begin{array}{l}\text { Many parents understand the } \\
\text { Importance of education for } \\
\text { children }\end{array}$ & $\begin{array}{l}\text { There are some parents who } \\
\text { were not present in the } \\
\text { socialization of the importance } \\
\text { of education for children }\end{array}$ \\
\hline & & $\begin{array}{l}\text { Many parents become } \\
\text { open-minded, the meaning of } \\
\text { education for the future of } \\
\text { children in the face of } \\
\text { increasingly difficult life } \\
\text { competition }\end{array}$ & $\begin{array}{l}\text { There are some parents who } \\
\text { have permission to leave the } \\
\text { event before the event starts }\end{array}$ \\
\hline & & Many people become aware & There are some people who play \\
\hline
\end{tabular}




\begin{tabular}{|c|c|c|c|}
\hline & & $\begin{array}{l}\text { of the importance children to } \\
\text { the highest level or level }\end{array}$ & cellphones during socialization \\
\hline \multirow[t]{2}{*}{2} & \multirow[t]{2}{*}{$\begin{array}{l}\text { at the time of the } \\
\text { formation of study } \\
\text { groups }\end{array}$} & $\begin{array}{l}\text { Many students are happy } \\
\text { with group learning so that } \\
\text { their entire homework (PR) is } \\
\text { not a personal burden but } \\
\text { can be discussed in group } \\
\text { learning, }\end{array}$ & $\begin{array}{l}\text { Many students are far from their } \\
\text { homes, so they feel objected, }\end{array}$ \\
\hline & & $\begin{array}{l}\text { Students who have not done } \\
\text { the assignments or just } \\
\text { imitated their friends have } \\
\text { become more active in their } \\
\text { work }\end{array}$ & $\begin{array}{l}\text { The number of male and female } \\
\text { students is a lot that is not } \\
\text { balanced, so that groups with } \\
\text { very few female students or only } \\
\text { one becomes less able to } \\
\text { socialize in their groups }\end{array}$ \\
\hline \multirow[t]{3}{*}{3} & \multirow[t]{3}{*}{$\begin{array}{l}\text { Implementation of } \\
\text { Community Learning } \\
\text { Hours }\end{array}$} & $\begin{array}{l}\text { Society becomes concerned } \\
\text { about children's learning time, }\end{array}$ & $\begin{array}{l}\text { There are some community } \\
\text { members who do not care about } \\
\text { children who are still out of the } \\
\text { house during study hours, }\end{array}$ \\
\hline & & $\begin{array}{l}\text { the community becomes ware } \\
\text { of children's learning time, } \\
\text { so they do not turn on the } \\
\text { TV during study hours; }\end{array}$ & $\begin{array}{l}\text { There are some parents who turn } \\
\text { on the TV during study hours; }\end{array}$ \\
\hline & & $\begin{array}{l}\text { Children learn hard at home } \\
\text { during study hours and do } \\
\text { not play outdoors }\end{array}$ & $\begin{array}{l}\text { Some children only play } \\
\text { cellphones during study hours }\end{array}$ \\
\hline \multirow[t]{3}{*}{4} & \multirow[t]{3}{*}{$\begin{array}{l}\text { when studying in } \\
\text { groups }\end{array}$} & $\begin{array}{l}\text { Children become active group } \\
\text { learning }\end{array}$ & $\begin{array}{l}\text { There are some children who do } \\
\text { not come in group study } \\
\text { schedules }\end{array}$ \\
\hline & & $\begin{array}{l}\text { Children's learning spirit } \\
\text { increases, }\end{array}$ & $\begin{array}{l}\text { When it comes to group learning, } \\
\text { there are some children who only } \\
\text { play cellphones not to study } \\
\text { seriously, }\end{array}$ \\
\hline & & $\begin{array}{l}\text { The enthusiasm for the } \\
\text { teacher increases especially } \\
\text { when the teacher visits his } \\
\text { group.. }\end{array}$ & $\begin{array}{l}\text { There are children who come to } \\
\text { the place of study only to get a } \\
\text { good assessment from their } \\
\text { teacher. So when at school, the } \\
\text { teacher asks, anyone who is } \\
\text { diligent in participating in group } \\
\text { learning, the name of the child is } \\
\text { mentioned by other group } \\
\text { members }\end{array}$ \\
\hline \multirow[t]{4}{*}{5} & \multirow[t]{4}{*}{$\begin{array}{l}\text { Learning Assistance } \\
\text { Training }\end{array}$} & $\begin{array}{l}\text { Parents become aware of how } \\
\text { to accompany correct learning }\end{array}$ & $\begin{array}{l}\text { There are some parents who did } \\
\text { not attend the Learning } \\
\text { Assistance Training for Parents }\end{array}$ \\
\hline & & $\begin{array}{l}\text { The motivation of parents to } \\
\text { Accompany children in } \\
\text { learning increases }\end{array}$ & $\begin{array}{l}\text { There are some parents who are } \\
\text { not serious in participating in } \\
\text { training, }\end{array}$ \\
\hline & & $\begin{array}{l}\text { Parents know various } \\
\text { difficulties faced by children }\end{array}$ & $\begin{array}{l}\text { There were some parents who } \\
\text { left the event even though the } \\
\text { event was not finished }\end{array}$ \\
\hline & & $\begin{array}{l}\text { Parents know the various } \\
\text { advantages that children have }\end{array}$ & $\begin{array}{l}\text { There are some parents who } \\
\text { keep on playing HP even }\end{array}$ \\
\hline
\end{tabular}




\begin{tabular}{|c|c|c|c|}
\hline & & & though the event is ongoing \\
\hline \multirow[t]{3}{*}{6} & \multirow[t]{3}{*}{ visiting teacher visit } & $\begin{array}{l}\text { The teacher knows the } \\
\text { family background of their } \\
\text { students. }\end{array}$ & $\begin{array}{l}\text { There are some teachers who } \\
\text { only come to the group } \\
\text { learning location to just fulfill } \\
\text { the duties of the headmaster. }\end{array}$ \\
\hline & & $\begin{array}{l}\text { The teacher knows the spirit } \\
\text { of learning the child in the } \\
\text { study group.. }\end{array}$ & $\begin{array}{l}\text { There are some teachers who } \\
\text { only briefly look at group } \\
\text { learning without taking the time } \\
\text { to receive questions from } \\
\text { students or answer student } \\
\text { questions.. }\end{array}$ \\
\hline & & $\begin{array}{l}\text { The teacher knows the } \\
\text { support or participation of } \\
\text { parents in paying attention to } \\
\text { the seriousness of children's } \\
\text { learning }\end{array}$ & $\begin{array}{l}\text { The frequency of teachers } \\
\text { visiting student study groups for } \\
\text { too long, causing many students } \\
\text { who are disappointed because } \\
\text { they want to ask various } \\
\text { difficulties to the teacher }\end{array}$ \\
\hline
\end{tabular}

Source: results of data analysis.

Follow Up on Model Implementation Evaluation Results

1. The steps taken by researchers are to discuss with the actors to improve all activities that are felt by researchers. In this case the researcher conducted discussions with stakeholders:

2. RT will try to increase public awareness through various appeals and cooperation, especially when many school-age children are still outside the house during Community Learning Hours (18:00 - 20:00)

3. Discuss with the teacher, to increase the intensity of conducting study group visits, so that it is expected to be able to pump up children's learning spirit;

4. Discuss with community leaders, to increase their awareness in supervising the implementation of community learning hours, so that the implementation of community learning hours can be effective.

5. Discuss with youth leaders, to help parents in supervising elementary and middle schoolaged children, so that they can use their learning time well.

6. Discuss with religious leaders, to always monitor children's learning both at the mosque, mosque, and at their homes.

\section{Conclusion}

1) The implementation of the model is carried out by active participation of the community and schools and the alignment of related institutions such as the neighborhood association (RT), the neighborhood association (RW), the village head (Lurah), the head of the subdistrict (Camat), and local government, as well as parties from the campus is very important for increasing parents' awareness of children's education according to the model produced in first years.

2) in the implementation of the model (year 2) there are still obstacles, including assistance from the sub-district and city districts is still lacking. Regarding the motivation (and mindset) of the community to send their children to school is higher than when they do not have an understanding of the meaning of education for children. 
Based on the conclusion, it can be suggested:

1. Local governments should be more pro-active in working together to increase parents' awareness of children's education.

2. The neighborhood association (RT), the neighborhood association (RW), the village head (Lurah), the head of the sub-district (Camat), should also play an active role in increasing the rate of continuing school, and lowering the achievement of drop out.

\section{Reference}

[1]. Basrowi dan Sukidin. 2003. Teori-Teori Perlawanan dan Kekerasan Kolektif. Surabaya : Penerbit Insan Cendekia

[2]. Keraf, Sony. 2006. Etika Lingkungan. Kompas, Jakarta

[3]. Mustain. 2007. Petani VS Negara: Gerakan Sosial Petani Melawan Hegemoni Negara. Yogyakarta : AR-Ruzz Media.

[4]. Qodariayah, L, dan Armiyati, L, 2013. Nilai-Nilai Kearifan Lokal Masyarakat Adat Kampung Naga sebagai Alternatif Sumber Belajar. Socia. Vol 10. No 1.

[5]. Soerjani, M; Rofiq Ahmad dan Rozy Munir, 1987. Lingkungan: Sumberdaya Alam Dan Kependudukan Dalam Pembangunan, UI Press, Jakarta.

[6]. Soerjono Soekanto. 1982. Teori Sosiologi Tentang Pribadi dalam Masyarakat. Jakarta: Ghalia Indonesia.

[7]. Yunita, T Winarto. 1986. "Perberdaan Antara Interpretasi Neofungsionalisme dan Tindakan Individu yang Rasional", dalam Berita Antropologi. Jurusan Antropologi Fakultas Ilmu Sosial dan Ilmu Politik, Universitas Indonesia. Jakarta. Halaman 66-8

[8]. Zaremba, Y.V. dkk. 2014. Nilai-Nilai Kearifan Lokal Sasak Berwawasan Multikultural Guna Membangun Integrasi Sosial Masyarakat Di Lombok Barat. Universitas Pendidikan Indonesia. repository.upi.edu /perpustakaan.upi.edu 